Journal of Life Economics

Cilt / Volume 7, Say1 / Issue 2, 2020, pp. 177-188

E - ISSN: 2148-4139

URL: https://www.ratingacademy.com.tr/ojs/index.php/jlecon

DOI: https://doi.org/10.15637/jlecon.7.012

Araştırma Makalesi/Research Article

\title{
FISCAL DEFICITS AND INTEREST RATES IN BRICS ECONOMIES: TESTING THE KEYNESIAN-RICARDIAN OPPOSITION
}

\author{
Edward Kagiso MOLEFE* \& Gisele MAH ** \\ * Lecturer in Department of Economics and Finance, \\ University of the Free State, South Africa, e-mail: molefeek@ufs.ac.za \\ ORCID: https://orcid.org/0000-0002-2965-8792 \\ ** Professor in School of Economic Sciences, North-West University, \\ South Africa e-mail: Gisele.Mah@nwu.ac.za \\ ORCID: https://orcid.org/0000-0002-8729-9935
}

Received: 3 April 2020; Accepted: 30 April 2020

\begin{abstract}
This current study was aimed at exploring the consequential effects of both short-and long-term interest rates on fiscal deficits in BRICS economies. The panel vector error correction model (PVECM) techniques were employed to capture both long-run and short-run dynamics between variables. Using annual panel data, spanning the period 1995 to 2019, which was derived from OECD and IMF, this current study discovered a positive and significant relationship between both short- and long-term interest rates in BRICS economies. Moreover, the results of the study revealed a negative and significant relationship between GDP and fiscal deficits. These results confirmed that fiscal deficits hypothetically crowd out private investment and consumption through increased effects on interest rates. Therefore, the implementation of policy mix (interaction between monetary policy and fiscal policy) was recommended to unnecessary or unproductive government expenditure that may result in increased fiscal deficits and interest rate in BRICS economies.
\end{abstract}

Keywords: fiscal deficits, interest rates, inflation, gross domestic product

JEL Codes: H62, E62, E31, C23 


\section{INTRODUCTION}

The 2007-08 US financial crisis was regarded as one of the drastic global economic predicaments following the 1930 Great Depression. The crisis commenced in 2007 following a massive decline in the subprime mortgage market in the United States. Regardless of the efforts taken by the Federal Reserve and Treasury to prevent it, the crisis led to the great recession affecting other countries. According to Kelikume (2016), this global economic crisis extensively affected both advanced and emergent economies. This was a clear indication that "when America sneezes, the rest of the world catches a cold". According to Kelikume (2016), this global economic crisis led to increased government borrowing from the domestic and international markets to finance the ongoing operation.

The effects of this increased government borrowing due to the 2007-08 global crisis raised the age-old debated regarding the linkage between government budget deficits, increased interest rates and shrinking investments. Even though this linkage has been an empirical question for some time, the debate is still mushrooming with agreements occasionally emerging but not persisting. For instance, according to Molefe and Maredza (2017), the increased government borrowing stimulates the expansion of public debt or budget deficits and thereby crowds out both private sector investment and consumption through increased interest rates. In contrast, Mukhtar and Zakaria (2008) and Bayat, Kayhan and Senturk (2012) argued that there is no way that budget deficits and its proportion to GDP can affect interest rates.

Up to this current moment, no coherent agreement exists between scholars and policymakers regarding the link between fiscal deficits and interest rates. Therefore, this current study examines the effects of interest rates on government budget deficits in BRICS countries. However, unlike previous studies that focused on assessing the effects of total interest rates on fiscal deficits, this current study decomposes interest rates into short-term and long-term interest rates. Moreover, this study will provide a beneficial empirical framework that will assist in policy formulation in BRICS economies and other emerging economies. It can be of use to policymakers tackling snowballing debt and widening budget deficits, since they continue posing threats to economic stability.

\section{FISCAL DEFICITS IN BRICS ECONOMIES}

BRICS is the ellipsis that signifies a partnership between five emergent countries, namely Brazil, Russia, India, China as well as South Africa. This partnership is known for its fastest developing economies and their considerable influence on both regional and world-wide affairs. According to BRICS Quarterly Bulletin (2013), BRICS was formed to address economic challenges such as infrastructural developments and to further intensify trade between the above-mentioned countries. According to the National Treasury's BRICS report of 2012, BRICS economies remain significant and continue to contribute to the world's economic affairs. It represents more than 40 per cent of the world's population with China and India leading the world. Furthermore, it accounts for 30 per cent land mass and a 25 per cent share of the global GDP in PPP terms.

According to Ang (2016), China, Brazil, Russia and India are ranked top 10 in the G-20 with more than 55 per cent contribution to growth of PPP in the year 2000 and 2008. Most of the economic challenges experienced by BRICS economies came to effect with the 2008/09 financial crisis where the monetary policy was ineffective. During the same financial crisis, BRICS's fiscal stability started weakening with budget deficits and public debt increasing above the controllable rate (see Figure 1). This transpired due to the fiscal policy interventions to improve the economy. 
Figure 1: Deficit (-)/surplus of general government to GDP in BRICS countries from 2005 to 2015

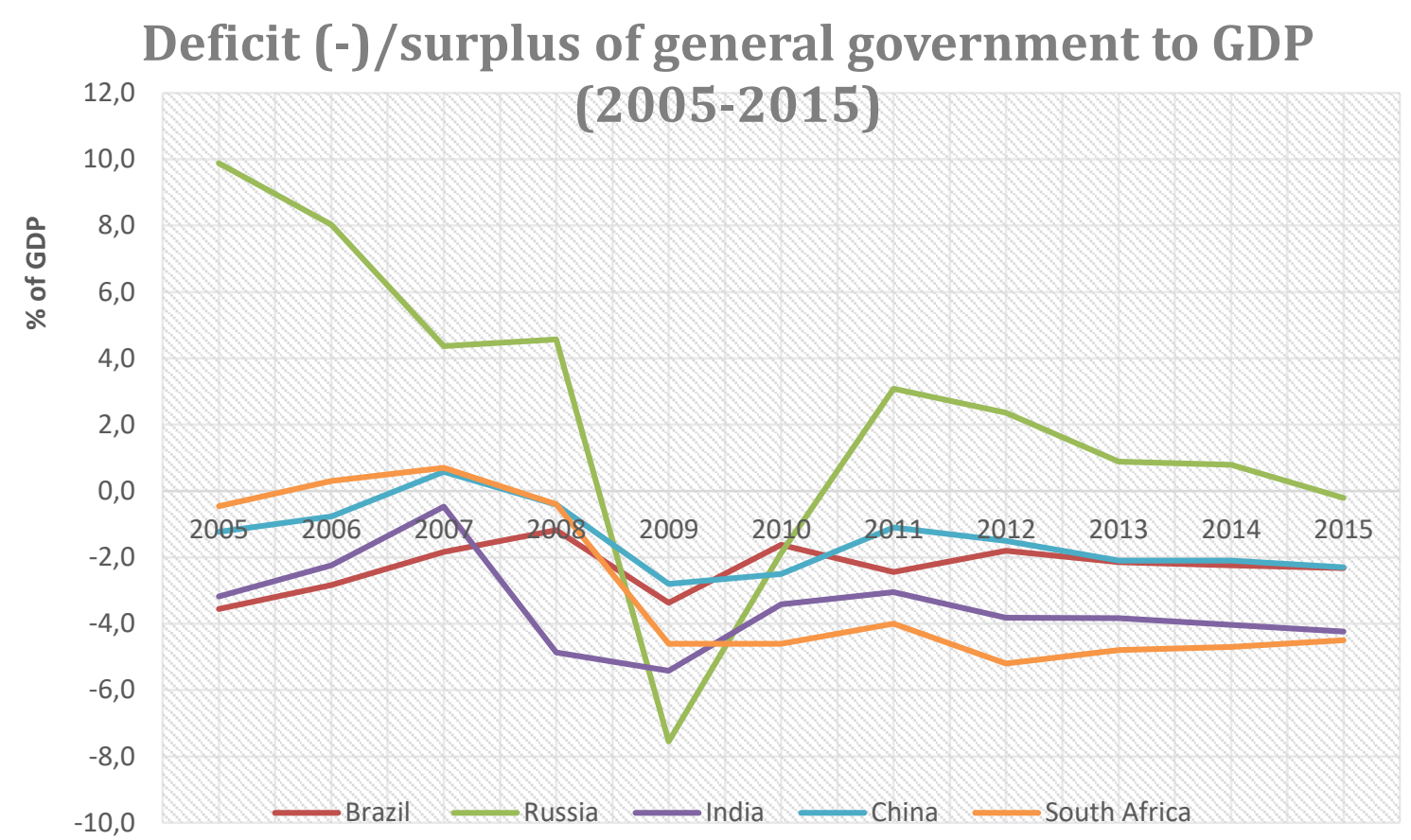

Source: Author's compilation using data from World Bank development indictors

Based on Figure 1, almost all BRICS economies have been experiencing budget instabilities throughout the years. Nonetheless, BRICS economies began to be fiscal cautious and implemented economic responsive policies such as fiscal consolidation, which was aimed at reducing budget deficits by two-fold in a three-year period. The Fiscal Responsibility and Budget Management (FRBM) Act, Fiscal Responsibility Law (FRL) and Growth, Economy and Redistribution (GEAR) were among the policies that were implemented by individual countries among BRICS. Nevertheless, according to the BRICS report of 2017, these policies did not necessarily assist countries to recover. Instead, BRICS economies continued experiencing fiscal instabilities due to countercyclical expansionary fiscal measures implemented by governments to enhance the domestic demand. Up to the present time, BRICS countries are still experiencing increasing budget deficits.

\section{LITERATURE REVIEW}

The fiscal deficit-interest rates nexus can be traced back as far as the Mundel-Flemming model, which assumed an increase in fiscal deficits as a result of increasing interest rates. Since then, this model has attracted much theoretical and empirical debate between scholars and policymakers in both developed and developing countries. Theoretically, there exist two deviating schools of thought regarding the relationship in question. Such schools of thought are the conventional Keynesian view and the Ricardian deficit neutrality. According to Molefe and Choga (2017), the conventional Keynesian view supported fiscal deficits as one of the indispensable fiscal policies to enhance aggregate demand, since increasing interest rates would fail dismally. According to Keynes (1937), an economy with no government intervention would collapse as it was evident during the 1939 Great Recession.

On the other hand, Ricardian deficit neutrality, endorsed by Barro (1989, 1990), presented a different assumption. According to Barro (1990), fiscal deficits do not really matter since they are just meritoriously equivalent to future increased tax liabilities. The Ricardian 
equivalence proposition was regarded as an economic hypothesis that assumes that consumers are forward looking and take into consideration the government's budget constraints when making individual consumption decisions. According to Barro, extra savings by consumers would balance the additional expenditure of the government and as a result, total demand would remain unchanged. Therefore, government intervention to stimulus demand by means of fiscal policy will be ineffective.

In response to the above-mentioned arguments, numerous studies were conducted to scrutinise the relationship in question. However, the paradox still exists in both advanced and emerging economies. For instance, Ahmad (2005) did a study in Pakistan using quarterly time series data spanning 1960 to 2005. The results of the study revealed that there exists no relationship between budget deficits and interest rates in Pakistan. The results of the study confirmed the existence of Ricardian deficit neutrality in the Pakistan economy. Mukhtar and Zakaria (2008) and Bayat, Kayhan and Senturk (2012) also supported Ahmad's results and argued that there is no way budget deficits and its proportion to GDP are related to interest rates.

Dai and Philippon (2004) also analysed the relationship in question by means of noarbitrage structural VAR techniques. To allow the study to integrate the cross-sectional information in bond yields into an underlying macroeconomic framework, the results of the study discovered that government deficits are a significant factor behind the yield curve. Using the vector-autoregression methods, Obi and Nuredeen (2009) and Bonga-Bonga (2011) also discovered a positive relationship between the variables under study.

To date, regardless of the number of studies undertaken, the alleged relationship is still not clear in numerous countries. The debate is still mushrooming and has led to division between scholars and policymakers; hence this current study. This current study seeks to assess the relationship in question in BRICS countries. This will assess whether there exists a crowding-out theory or the Ricardian deficit neutrality in BRICS economies.

\section{DATA AND METHODOLOGY}

This current study used the annual panel data covering the period 1995 to 2019 to examine the relationship between fiscal deficits and interest rates in BRICS economies. Macroeconomic and monetary variables such as short-term interest rates or treasury bill rates, long-term interest rates, inflation, and gross domestic product are incorporated in the model estimated to study the their effects on fiscal deficit or deficit (-)/surplus of general government. This follows a wide acknowledgement that when the monetary policy is ineffective, the fiscal policy remains the only tool to correct the economy, and from there the increasing budget deficits.

\subsection{Model estimation}

In order to examine both short-run and long-run dynamics between dependent and independent variables, this study adopted the panel vector error correction model (PVECM). Annual panel data spanning the period 1995 to 2019 was derived from World Bank development indicators, OECD and IMF dataset. In this current study, fiscal deficits (FDIF) were expressed as the depended variable. Therefore, the model can be written in a functional form as: 
Where FDIF - fiscal deficits

LIR - long-term interest rates

SIR - short-term interest rates

INF - inflation

GDP - gross domestic product

The above model is hereby written in linear form as:

$\Delta F D I F_{t}=\sum_{j=1}^{n} \mu j L I R_{t-1}+\sum_{j=1}^{n} \delta j S I R_{t-1}+\sum_{j=1}^{n} \alpha j I N F_{t-1}+\sum_{j=1}^{n} \emptyset_{j} G D P_{t-1}+\varepsilon_{t}$

\subsection{Estimation techniques.}

\subsubsection{Panel unit root test.}

To estimate the econometric model, it is advisable to firstly assess if the variables employed are stationary. According to Asteriou and Asteriou (2011), this process assist in ensuring that the study does not produce spurious regression results by relying on variables that are non-stationary. Though quite a few procedures have been proposed by considering different assumptions, there is no homogeneously powerful test for unit root. Therefore, this study employs the Levin, Lin and Chut (LLC) and Im, Pesaral and Shin (IPS) tests of unit root.

The Levin, Lin and Chut unit root test use the augmented Dickey Fuller (ADF) specification by considering the following model:

$$
\Delta \gamma_{\mu}=\rho \gamma_{t, t-1}+\sum_{L=1}^{\rho i} \theta i L \Delta \gamma_{i t-L}+\alpha_{m i} d_{m i}+\varepsilon_{i t}
$$

Where:

$m=1,2,3 d_{m t}$ are the vectors of deterministic variables, and

$a_{m i}$ denotes the equivalent vector of coefficient for model $m=1,2,3$.

The Levin, Lin and Chu unit root test also takes into consideration the fixed effects and individual time trends for each country. It permits the lag order $\rho_{i}$ not to be the same for individual cross-section units. The null hypothesis of the LLC test clearly explain that each individual time series has a unit root contrary to the alternative, which states that each time series is stationary. The hypothesis can be written as follows:

$$
\begin{gathered}
H_{0}: \rho=0 \\
H_{1}: \rho<0 .
\end{gathered}
$$


The Im, Pesaral and Shin test consider the mean of ADF statistics calculated for each cross-section unit in the panel when the error term $\varepsilon_{t}$ of the model is serially correlated, possibly with different serial correlation patterns across cross-sectional units. The IPS model applied in this study will be calculated using the following equation:

$$
\Delta y_{i t}=\alpha_{o i}+\rho_{i} y_{i t-1}+\sum_{j=1}^{\rho i} \theta i j \Delta \gamma_{i t-j}+\varepsilon_{i t}
$$

Where $i=1,2, \ldots, N, t=1,2, \ldots, T$

The hypothesis that is tested can be written as follows:

$H_{0}: \rho *=0$ for all $i$

Against the alternative:

$$
H_{1}:\left\{\begin{array}{c}
\rho i<O \text { for } i=1, \ldots N 1 \\
\rho i=0 \text { for } i=N 1+1, \ldots, N
\end{array} \text { with } 0<N 1 \leq N\right.
$$

\subsubsection{Panel cointegration test}

The concept cointegration is extensively used in literature to test the existence of long run relationships amongst variables employed. Like in the individual unit root test, cointegration tests in time series literature suffer from low value when the time horizon is short. Panel techniques are considered better in detecting cointegration since a pooled levels regression combines cross-sectional and time series information in the data when estimating cointegration coefficients. To test for cointegration between variables, this study employed the Fisher cointegration test

The Fisher-type cointegration syndicates the individual Johansen's trace and maximum eigenvalue test. The trace statistic tests for at most $r$-cointegrating vectors among a system of $\mathrm{N}>\mathrm{r}$ time series, whereas the maximum eigenvalue statistics test for exactly $\mathrm{r}$-cointegrating vectors against the alternative hypothesis of $r+1$ cointegrating vectors. If the $\pi$ is the $p$-value from an individual cointegration test for cross-sectional $i$, then, under null hypothesis for the entire panel, $-2 \Sigma \log m i=1(\pi i)$ is distributed as $\sim x 2 n 2$. The $x 2 n 2$ is a chi-square distribution with $2 N$ degree of freedom.

\subsubsection{Panel Vector Error Correction Model (PVECM).}

According to Engle and Granger (1987) if two or more series are cointegrated they can be considered as being generated by an error correction mechanism. However, the existence of a cointegration relationship cannot explain the direction of causality among the variables. Therefore, in order to examine the direction of causality, a panel vector error correction model (PVECM) should be conducted. The PVECM is a restricted panel vector autoregression (PVAR) model with a cointegration built into its condition. This current study employ the PVECM as shown as follows:

$$
\Delta F D I F_{t}=\sum_{j=1}^{n} \mu j L I R_{t-1}+\sum_{j=1}^{n} \delta j S I R_{t-1}+\sum_{j=1}^{n} \alpha j I N F_{t-1}+\sum_{j=1}^{n} \emptyset j G D P_{t-1}+\varepsilon_{t}
$$

Where:

$\varepsilon_{t^{-}}$a scalar disturbante, and

$t$-indexes time measured in years. 


\subsubsection{Wald coefficient test.}

This current study employs the coefficient test (Wald test) to measure the closeness of the unrestricted estimates to satisfy the restrictions under the null hypothesis. If the restrictions are in fact true, then the unrestricted estimates should come close to satisfying the restrictions. General formula for the Wald test statistic is as follows:

$$
\mathrm{W}=n g(b)^{\prime}\left(\frac{\partial g}{\partial \beta} v \frac{\partial g}{\partial \beta \prime}\right)^{-1} g(b)
$$

Where:

$n$ is the number of observations,

$b$ is the unrestricted parameter estimates.

$V$ is the estimated variance of $b$ given by:

$$
\mathrm{V}=n s^{2}\left(\frac{\partial x}{\partial \beta} \frac{\partial x}{\partial \beta}\right)^{-1}, s^{2}=\frac{u \prime u}{n-k}
$$

Where

$u$ is the unrestricted residual.

Under the null hypothesis, the Wald statistic has an asymptotic $(q)$ distribution, where $q$ is the number of restrictions.

\subsection{Explanation of variables and prior expectation}

Fiscal deficits are the dependent or explained variable and are derived by subtracting total government expenditure from the total government collected revenue

Long-term interest rates are the government bond maturing in a ten-year period. This study assumes a positive correlation between long-term interest rates and fiscal deficits.

Short-term interest rates are the rates at which short-term government paper is issued or traded in the market. This study assumes a positive correlation between short-term interest rates and fiscal deficits.

Gross domestic product is the aggregate market value of all final goods and services manufactured annually within the border lines of the country. This current study assumes a negative correlation between gross domestic product and fiscal deficits.

Inflation is referred to as an overall increase in price and fall in the purchasing value of money. This current study assumes a positive correlation between inflation and fiscal deficits.

\subsection{Motivation of variables}

The reason for studying the relationship between interest rates and fiscal deficits is due to that numerous countries that finance the deficit through borrowing, which later enlarges government's demand for credit. This automatically puts pressure on interest rates and decelerates the rate of capital formation. According to Biza, Kapingura and Tsegaye (2015), a decelerating rate of capital formation reduces investment purchase through the transmission mechanism.

In other countries, the government deficit is said to be monetised when the central bank purchases the government bonds to cover its deficits. This process increases money in the economy and results in inflation; therefore, it is included in the model. 
GDP is included in the model as an indicator of the aggregate economic condition. For instance, in periods of economic boom, the deficit is lower, and during recession, it is higher, since more public spending is required to stabilise the economy at the same time as taxes are reducing.

\section{DATA ANALYSIS AND INTERPRETATION OF RESULTS}

Stationarity test remains one of the important exercises in econometrics when estimating a model (Asteriou and Hall, 2011). Therefore, the Levin, Lin and Chu test and the Im, Pesaral and Shin test of stationarity were employed. The results of both tests are presented in Table 1 and 2 as follows:

Table 1: Levin, Lin and Chu test results

\begin{tabular}{|c|c|c|c|c|}
\hline \multirow{2}{*}{$\begin{array}{l}\text { Levin, Lin and } \\
\text { Chu test }\end{array}$} & \multicolumn{2}{|c|}{ Levels } & \multicolumn{2}{|c|}{ First difference } \\
\hline & $\begin{array}{l}\text { Individual } \\
\text { effects }\end{array}$ & $\begin{array}{l}\text { Individual effects } \\
\text { \& trends }\end{array}$ & $\begin{array}{l}\text { Individual } \\
\text { effects }\end{array}$ & $\begin{array}{l}\text { Individual effects } \\
\text { \& trends }\end{array}$ \\
\hline$F D I F$ & $\begin{array}{l}-3.831 \\
(0.610)\end{array}$ & $\begin{array}{l}-2.418 \\
(0.340)\end{array}$ & $\begin{array}{l}-5.876 \\
(0.000)^{* * *}\end{array}$ & $\begin{array}{l}-5.322 \\
(0.000) * * *\end{array}$ \\
\hline LIR & $\begin{array}{l}-0.992 \\
(0.761)\end{array}$ & $\begin{array}{l}-1.145 \\
(0.127)\end{array}$ & $\begin{array}{l}-5.908 \\
(0.000)^{* * *}\end{array}$ & $\begin{array}{l}-5.226 \\
(0.000)^{* * *}\end{array}$ \\
\hline SIR & $\begin{array}{l}0.412 \\
(0.304)\end{array}$ & $\begin{array}{l}-0.267) \\
(0.319)\end{array}$ & $\begin{array}{l}-7.167 \\
(0.000) * * *\end{array}$ & $\begin{array}{l}-6.506 \\
(0.000) * * *\end{array}$ \\
\hline INF & $\begin{array}{l}-1.355 \\
(0.809)\end{array}$ & $\begin{array}{l}0.483 \\
(0.669)\end{array}$ & $\begin{array}{l}-5.769 \\
(0.000) * * *\end{array}$ & $\begin{array}{l}-5.231 \\
(0.000) * * *\end{array}$ \\
\hline$G D P$ & $\begin{array}{l}-2.319 \\
(0.016)^{* *}\end{array}$ & $\begin{array}{l}-3.148 \\
(0.000)^{* * *}\end{array}$ & $\begin{array}{l}-7.285 \\
(0.000)^{* * *}\end{array}$ & $\begin{array}{l}-7.119 \\
(0.000)^{* * *}\end{array}$ \\
\hline
\end{tabular}

Note: $* 10 \%$ statistically significant, $* * 5 \%$ statistically significant, $* * * 1 \%$ statistically significant

Table 2: Im, Pesaral and Shin test results

\begin{tabular}{c}
\multirow{3}{*}{$\begin{array}{c}\text { Im, Pesaran } \\
\text { and Shin test }\end{array}$} \\
\cline { 2 - 6 }
\end{tabular}

Note: $* 10 \%$ statistically significant, $* * 5 \%$ statistically significant, $* * * 1 \%$ statistically significant

Using the equation type based on individual effects and also individual effects and trends, both LLC and IPS results revealed that variables, except GDP, are non-stationary at levels. The variables became stationary when they are differenced; therefore, the study rejected the null hypothesis of non-stationarity since the stationarity presence was observed at first difference. The study therefore concluded that variables are stationary and integrated at same order of $\mathrm{i}(1)$. 
Since the stationarity was confirmed, the study proceeded to cointegration. Using the Fisher-Johansen technique, the cointegration was tested using the lag of 1 as suggested by the lag order selection of criterion. The results of the Fisher panel cointegration test are presented in Table 3 as follows:

Table 3: Fisher Johansen cointegration results

\begin{tabular}{c|c|c|c|c}
$\begin{array}{c}\text { Hypothesised } \\
\text { no. of } C E(s)\end{array}$ & $\begin{array}{c}\text { Fisher stat.* } \\
\text { (from trace test) }\end{array}$ & Prob & $\begin{array}{c}\text { Fisher stat.* } \\
\text { (from max-eigen test) }\end{array}$ & Prob \\
\hline \multirow{2}{*}{$\begin{array}{c}\text { None } \\
\text { At most 1 }\end{array}$} & 112.6 & 0.000 & 83.52 & 0.000 \\
\cline { 2 - 5 } At most 2 & 44.36 & 0.020 & 29.62 & 0.045 \\
\cline { 2 - 5 } At most 3 & 21.08 & 0.120 & 14.01 & 0.172 \\
\cline { 2 - 5 } At most 4 & 14.72 & 0.142 & 12.21 & 0.271 \\
\cline { 2 - 5 } & 16.11 & 0.096 & 16.11 & 0.096 \\
\hline
\end{tabular}

Based on the Fisher Johansen test results, there exists one cointegrating equation and this was determined using the probability value. The probability values for the hypothesised number of $\mathrm{CE}(\mathrm{s})$ were significant at None and at Most 1, while others were insignificant using the study's benchmark of 5\% level of significance. Since the cointegration relationship was established, the study proceeded to estimate the panel vector error correction model (PVECM) to disaggregate the long-run and the short-run effects of the variables. The PVECM results are presented in Tables 4 and 5 below:

Table 4: Long-run estimate: FDIF

\begin{tabular}{l|l|l|l|} 
Variable(s) & Coefficient & Standard errors & t-statistics \\
\hline $\operatorname{LIR}(-1)$ & 3.235 & 0.423 & 5.043 \\
$(-1)$ & 2.064 & 0.507 & 5.106 \\
$\operatorname{INF}(-1)$ & 0.296 & 0.106 & 0.631 \\
$\operatorname{GDP}(-1)$ & -1.162 & 0.642 & 2.953 \\
\hline
\end{tabular}

The long-run results, as shown in Table 5, suggested that there is a significant positive relationship between fiscal deficits and long-run interest rates. This implies that a $1 \%$ increase in long-term interest rates is associated with a 3.2\% increase in fiscal deficit. Moreover, the results revealed a significant and positive relationship between short-term interest rates and fiscal deficits. A $1 \%$ increase in short-term interest rates will increase budget deficits by $2.1 \%$ in the long run. The significance level in the variables was determined using the t-statistics at its absolute value. These results were in support of the conventional crowding-out and were similar to those in literature (See Obi and Nuredeen, 2009, Dai and Philippon, 2004, and BongaBonga, 2011).

Furthermore, this study discovered a significant positive relationship between inflation rate and fiscal deficits. A $1 \%$ increase in inflation will lead to a $0.29 \%$ increase in fiscal deficits. On the other hand, GDP was found to be negatively related to fiscal deficits. A $1 \%$ increase in GDP will help government to reduce the fiscal deficits by $1.2 \%$. The conclusion that can be drawn from the results of this current study is that fiscal deficit hypothetically crowds out private investment through increased effects on interest rates. 
The VECM short-run effects are presented in Table 5 as follows:

Table 5: Short-run results

\begin{tabular}{|c|c|c|c|}
\hline Variable(s) & Coefficient & Standard errors & t-statistics \\
\hline CointEq1 & -0.291 & 0.076 & -3.985 \\
\hline$D(F D I F(-1))$ & -0.136 & 0.125 & -1.084 \\
\hline$D(\operatorname{LIR}(-1))$ & 0.204 & 0.146 & 1.398 \\
\hline$D(\operatorname{SIR}(-1))$ & 0.133 & 0.151 & 0.876 \\
\hline$D(\operatorname{INF}(-1))$ & 0.947 & 0.801 & 1.172 \\
\hline$D(G D P(-1))$ & -0.169 & 0.096 & -1.759 \\
\hline
\end{tabular}

The short-run results, as shown in Table 6, confirmed a significant and positive relationship of long-term, short-term interest rates and inflation towards fiscal deficits. Moreover, GDP was still negative in the short run. The study discovered that the coefficient of the error term is -0.29 , and it is statistically significant with a t-value of -3.99 . This implies that the speed of convergence to equilibrium when there is a shock is roughly $29 \%$.

To assess whether the explanatory variables in the model are significant, the study used the Wald test, also known as Wald chi-squared test. The Wald test results are present in Table 6 below:

Table 6: Wald test results

Test statistic

F-statistic

Chi-square
Value

6.489500

Df

$(2,100)$

2
Probability

\begin{tabular}{|c|c|}
\hline$(2,100)$ & 0.0721 \\
\hline 2 & 0.1570 \\
\hline
\end{tabular}

It is evident from Table 6 that the explanatory variables employed in the model are significant towards the explained variable. This was identified by the probability of the Chisquared, which was above the $5 \%$ level of significance.

\section{CONCLUSION AND POLICY RECOMMENDATION}

This study started by asking a question related to the relationship between fiscal deficits and interest rates in BRICS countries. To answer to this, the study employed the panel vector error correction modelling methods. Variables such as fiscal deficits, long-term interest rates, inflation, GDP and short-term interest rates were employed. The stationarity test was done using both LLC and IPS and it was revealed that variables under study are stationary at first difference. As a result, the null hypothesis of the non-stationarity was rejected and concluded that variables are integrated at the same order of 1 . The Fisher Johansen cointegration test was also performed and the results obtained confirmed the existence of one cointegrating equation.

The estimated PVECM revealed a positive and significant relationship between both long-term and short-term interest rates and fiscal deficits. Moreover, GDP was found to be negative and significantly related with fiscal deficits in BRICS countries. The conclusion that can be drawn from this current study was that fiscal deficits hypothetically crowd-out private investment in BRICS countries through increased interest rates. These results confirmed the existence of conventional crowding-out effects in BRICS economies. Therefore, this current study recommends the implementation of policy mix (interaction between monetary and fiscal policies) in order to ease unproductive government expenditure that may result in increased fiscal deficits and interest rates in BRICS economies. 


\section{REFERENCES}

AHMAD, N. (2013). The Role of Budget Deficit in the Economic Growth of Pakistan. Global Journal of Management and Business Research Economics and Commerce, 13(5): 1-5.

AL-MAJALI, A. (2018). Crowding Out Effect of Public Borrowing: The Case of Jordan. international Review of Management and Marketing, 8(1):119-125.

ANG, S. (2016). Comparing analysis of the BRICS trade. Contemporary Studies in Economic and Financial Analysis, 102(1):20-29.

ASTERIOU, D. \& Hall, S. (2011). Applied Econometrics, England: Palgrave Macmillan.

BARRO, R.J. (1989). The Ricardian Approach to Budget Deficits. Journal of Economic Perspective, 3(2):55-72.

BARRO, R.J. (1990). Government spending in a simple model of endogenous growth. Journal of Political Economy, 98(5): 103-125.

BIZA, R.A, Kapingura, F.M \& Tsegaye, A. (2015). Do budget deficits crowd out private investment? An analysis of the South African economy. International Journal of Economic Policy in Emerging Economies, 8(1): 52-76.

BONGA-BONGA, L. (2011). Budget Deficit and Long-Term Interest Rate in South Africa. African Journal of Business Management, 6: 3954-3961.

BRICS. (2013). The study of Brazil, Russia, India, China and South Africa with special focus on Synergies and complementary. United States of America: Oxford University Press.

BRICS. (2017). Key issues likely to dominate the 2017 BRICS Summit. Republic of South Africa. Centre for International Governance innovation.

BRICS (2018). The 2018 BRICS Finance Ministers and Central Bank Governors' Outcomes. Republic of South Africa.

DAI, Q \& PHILIPPON, T. (2004). Government Deficits and Interest Rates: A No-Arbitrage Structural VAR Approach. AFA 2005 Philadelphia Meetings. Available at SSRN: https://ssrn.com/abstract=642141 or http://dx.doi.org/10.2139/ssrn.642141.

FISHER R. A. (1932). Statistical Methods for Research Workers, Edinburgh: Oliver \& Boyd.

IM, K. S, PESARAN, M.H \& SHIN, Y. (2003). Testing for unit roots in heterogeneous panels. Journal of econometrics, 115(1): 53-74.

JOHANSEN, S. (1988). Statistical Analysis of Cointegrating Vectors. Journal of Economic Dynamic and Control, 12:231-54.

BAYAT, T, KAYHAN, S \& SENTURK, M. (2012). Budget deficits and interest rates: An empirical analysis for Turkey. Eurasian Journal of Business and Economics, 5 (9): 119128.

KELIKUME, I. (2016). The effect of budget deficit on interest rates in the countries of subSaharan Africa: A panel VAR approach. The Journal of Developing Areas, 50 (6): 105120.

KEYNES, J.M. (1936). The General Theory of Interest, Employment and Money, London: Macmillan.

LEVIN, A, LIN, C.F \& CHU, C.S.J. (2002). Unit root test in panel data: asymptotic and finite sample properties. Journal of Econometrics, 108(1):1-24. 
MOLEFE, K \& CHOGA, I. (2017). Government Expenditure and Economic Growth in South Africa: A Vector Error Correction Modelling and Granger Causality Test. Journal of Economics and Behavioral Studies, 9(4):164-172.

MOLEFE, K \& MAREDZA, A. (2017). Budget Deficits and Economic Growth: A Vector Error Correction Modelling of South Africa. Journal of Economics and Behavioral Studies, 9(2): 215-223.

MUKHTAR, T \& ZAKARIA, M. (2008). Budget deficits and interest rates: An empirical analysis for Pakistan. Journal of Economic Cooperation, 29(2):1-14

National Treasury. (2012). BRICS report of 2012. [online] available from http://www.treasury.gov.za/brics/Documents/brics-report.pdf

OBI, B, NUREDEEN, A \& WAFUNE, G. (2009). An empirical investigation of the Fisher Effect in Nigeria: A cointegration and error correction approach. International Review of Business Research papers, 5(1): 69-109.

ŞEN, H \& KAYA, A. (2014). Crowding-Out or Crowding-In? Analysing the Effects of Government Spending on Private Investment in Turkey. PANOECONOMICUS, 6(1): 631-651 